\title{
Microbial quality and proximate composition of dried Hibiscus sabdariffa calyxes in Uyo, Eastern Nigeria
}

\author{
Adebayo-tayo, B. C.* and Samuel, U. A \\ Department of Microbiology, University of Uyo, Uyo Akwa Ibom State, Nigeria \\ E-mail:bukola tayo@yahoo.com \\ Received 28 July 2008; received in revised form 15 November 2008; accepted 2 December 2008
}

\begin{abstract}
Dried Hibiscus sabdarifa calyxes collected from different markets in Uyo, Eastern Nigeria were evaluated for microbial quality, Aflatoxin contamination and proximate composition. The results showed that all the calyxes were contaminated with microorganism. The total bacteria count ranged from $5.0 \times 10^{3}$ to $8.1 \times 10^{4} \mathrm{cfu} / \mathrm{g}$ in which the highest count was obtained from dried calyxes from Itam Market. Coliform were not detected in most of the sample except samples from Uyo main market and Ikot Ekpene market in which the coliform level is below the acceptable limit. Salmonella/Shigella was not detected in the sample. The fungi count ranged from $3.4 \times 10^{4}$ to $7.3 \times 10^{4}$. The associated bacteria were Staphylococcus aureus, Bacillus subtilis, Bacillus sp. Enterococuss faecalis, Micrococcus sp. and Klebsiella sp. The associated fungi were Aspergillus flavus, A. terreus, A. glaucus, Penicillium citrinum, Fusarium oxysporum, Rhizopus sp. and Mucor sp. A. glaucus had the highest frequency of occurrence among the isolated fungi. Out of the sample obtained Aflatoxin $B_{1}$ was detected in two samples and it ranged from 1.57 to $17.8 / \mu \mathrm{g} / \mathrm{kg}$. The proximate analysis revealed that the crude protein ranged from $8.34-9.97 \%$, crude fibre $(7.26-7.82 \%)$ and fat $(8.51-9.26 \%)$. The moisture content ranged from $13.13-14.85 \%$.
\end{abstract}

Keywords: Hibiscus sabdariffa, calyxes, microbial quality, Aflatoxin, Aspergillus glaucus.

\section{INTRODUCTION}

Roselle (Hibiscus sabdariffa) an herbaceous upright plant species from the family Malvaceae is widely grown in the North Eastern and middle belt regions of Nigeria (Akanya et al., 1997). It is locally called "Zoborodo" (Hausa), "Isapa" (Yoruba) and Sorrel in English. Many parts of Roselle are of value, in countries like India, roselle calyxes are utilized in producing refreshing beverages, jellies, jam, sauces and food preserves. (Cyldescale et al., 1979). In Nigeria, the dried roselle calyxes are prepared into a nutritious refreshing drink called 'zobo'. The drink is becoming popular because it is easily prepared at home and served chilled, packed in plastic bottles or polyethylene films. It serves as income generation source for many women.

However, the dried calyxes like any other raw material or food is susceptible to deterioration by food borne microbes which can lead to reduction in quality of the drink in terms of color, taste and nutrition. Most of the fungal contaminant can cause spoilage and they are known to produce mycotoxins which are detrimental to human health. Aflatoxin, a group of toxic metabolites produced by certain Aspergillus species have been found to be carcinogenic, tetragenic and mutagenic to several species of experimental animals (Butler and Barnes 1998, Gopalan et al., 1972 and Adamson et al., 1973). Now despite the consumer acceptability of drinks from $H$. sabdariffa calyxes and physiochemical evaluation of the "zobo", (Amusa et al., 2005, Osuntogun and Aboaba 2004) inhibition of fungal isolates from sorrel drinks (llondu and Iloh 2007), fermentation studies on Roselle (Ojokoh et al., 2002), research has not been done on the microorganism that causes $H$. sabdariffa calyxes deterioration during storage.

The aim of this study was to investigate, detect and evaluate the presence of microorganism, aflatoxin and proximate composition of $H$. sabdariffa calyxes marketed in Akwa lbom State, Eastern Nigeria with special references to its public health hazard.

\section{MATERIALS AND METHODS}

\section{Collection of Samples}

Hibiscus sabdariffa calyxes (Red variety) were obtained from different spot in a local market in Uyo (Akpan Andem Market, Uyo main market, and Itam market) Akwa Ibom State, Nigeria.

One hundred grams of the calyxes were thoroughly washed in distilled water to remove sand and extraneous materials. $10 \mathrm{~g}$ of the washed calyxes was weighed into $90 \mathrm{~mL}$ sterile $0.1 \%$ peptone water as described in the Bacteriological Analytical Manual (FDA, 1991). Ten fold dilutions of each of the samples were made and $0.1 \mathrm{~mL}$ of the diluents were pour plated in triplicate plates on Nutrient agar for total bacteria counts, MacConkey agar (Oxoid) for coliform count, Salmonella/Shigella agar for 
Salmonella/Shigella counts and Sabourad dextrose agar with chloramphenicol $(250 \mathrm{mg} / 100 \mathrm{~mL})$ for fungal counts. All plates were incubated for $48 \mathrm{~h}$ at $30^{\circ} \mathrm{C}$ except Sabouraud Dextrose agar that were incubated at $26{ }^{\circ} \mathrm{C}$ for 6 days.

Colonies were selected randomly, bacteria cultures were characterized and identified using various morphological and biological test such as Gram stain, spore stain, motility, catalase, coagulase, indole, MR -VP, urease, citrate, oxidase and sugar fermentation. Pure cultures of each isolate were obtained by streaking the specific colonies on suitable media and incubated appropriately; these were maintained in an agar slant in McCartney bottles.

The identification of the microbial isolates was based on classification Scheme proposed by Harrigan and McCance (1976), Buchanan and Gibbson (1974) and Collin and Lyne (1984). The identification was based essentially on morphological and biochemical reactions. The associated fungi were then identified with reference to Barnet and Hunter (1972) and Frazier and Westholf (1998).

The proximate composition was carried out according to the method of Association of Official Analytical Chemists (1990). This includes determination of $\mathrm{pH}$, moisture content, ash content, crude fat, fiber, fat and crude protein and carbohydrate was determined by difference. The nutritionally essential elements $(\mathrm{Na}, \mathrm{K}, \mathrm{Ca}$ and $\mathrm{P})$ were determined using Atomic Absorption Spectrophotometer (AAS).

\section{Detection of aflatoxin in $H$. sabdariffa calyxes samples}

Aflatoxins were extracted from the calyxes according to the method of Seitz and Mohr (1977). Ten grams of the calyxes sample obtained from each of the markets were extracted with chloroform and concentrated.

Thin layer chromatography of aflatoxin and samples extracted were performed on silica gel DG 254 of the extracted sample in which 5,10 , and $15 \mathrm{~mL}$ were spotted on three different points on a ruled base line of the TLC plates. Also 5,10 and $15 \mathrm{~mL}$ of the aflatoxin standard were spotted on another three points near the previous sample extract spotted points. The plates were developed first with diethyl ether and then with chloroform acetone $(9: 1 \mathrm{v} / \mathrm{v})$. Aflatoxins were identified on the basis of comigration with aflatoxin standards (Fluka) and by their characteristic fluorescent color under long ultraviolet (UV) illumination at $360 \mathrm{~nm}$. The fluorescent spots of aflatoxins were scraped off the TLC and eluted by chloroform methanol $(9: 1 \mathrm{v} / \mathrm{v})$. The solvent was evaporated under nitrogen to dryness and the residue was dissolved in methanol. The concentration of aflatoxins $B_{1}$ in solution was determined by measuring its absorbance at $360 \mathrm{~nm}$ then calculated according to the method of Masri et al. (1969).

\section{Confirmatory test for aflatoxin}

Three different derivatives were prepared by treating portion of the isolated toxin on the aflatoxin standard with formic acid thionyl chloride, acetic-thionyl chloride and trifloroacetic acid. The test was then continuing according to the method of Stolloff (1976)

\section{RESULTS AND DISCUSSION}

The total plate counts, coliform count, Salmonella/Shigella count and fungi associated with dried $H$. sabdariffa calyxes are shown in Table 1 . The result showed that virtually all the calyxes' samples did not have coliform and Salmonella/Shigella excepts samples from Uyo market and Ikot Ekpene market in which the coliform count was below acceptable limit $\left(10^{2}\right.$ or WHO (1989) standard for food samples).

The total bacteria count ranged from $5.0 \times 10^{3}-1.1 \times$ $10^{4} \mathrm{cfu} / \mathrm{g}$ in which samples form lkot Ekpene market had the highest. The fungal count ranged from $3.6 \times 10^{4}-7.3$ $\times 10^{4} \mathrm{cfu} / \mathrm{g}$.

Table 1: Total count of microbial groups in the $H$. sabdariffa calyxes (cfu/g)

\begin{tabular}{llllll}
\hline Source & Sample & $\begin{array}{l}\text { Total bacteria } \\
\text { count }\end{array}$ & $\begin{array}{l}\text { Coliform count } \\
\text { (cfu/g) }\end{array}$ & $\begin{array}{l}\text { Salmonella/Shigella } \\
\text { count (cfu/g) }\end{array}$ & Fungal count (10 ${ }^{\mathbf{4}}$ ) \\
\hline Itam market & $\mathrm{A}_{1}$ & 8.1 & N.G & N.G & 3.6 \\
& $\mathrm{~B}_{1}$ & 6.4 & N.G & N.G & 3.4 \\
Akpan idem & $\mathrm{A}_{2}$ & 5.5 & N.G & N.G & 4.3 \\
market & $\mathrm{B}_{2}$ & 5.9 & N.G & N.G & 6.1 \\
Uyo main & $\mathrm{A}_{3}$ & 5.0 & $\angle 10^{2}$ & N.G & 5.4 \\
market & $\mathrm{B}_{3}$ & 7.9 & N.G & N.G & 4.9 \\
lkot Ekpene & $\mathrm{A}_{4}$ & 13.0 & $\angle 10^{2}$ & N.G & 7.3 \\
market & $\mathrm{B}_{4}$ & 11.0 & $\mathrm{~N} . \mathrm{G}$ & & \\
\hline
\end{tabular}

N.G - no growth 
Table 2: Microorganism associated with Hibiscus sabdariffa calyxes in Akwa lbom State

\begin{tabular}{|c|c|c|c|c|c|c|c|c|c|c|c|c|c|c|c|c|c|c|}
\hline 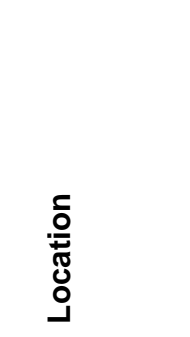 & $\begin{array}{l}\frac{0}{0} \\
\text { है } \\
\text { ले }\end{array}$ & 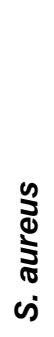 & 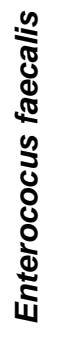 & 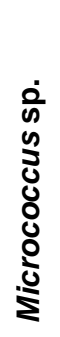 & 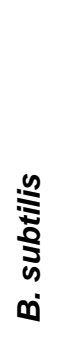 & 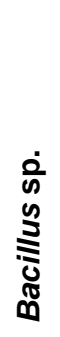 & $\begin{array}{l}\frac{0}{0} \\
\frac{0}{0} \\
\frac{0}{50} \\
\frac{0}{1} \\
\frac{1}{1}\end{array}$ & 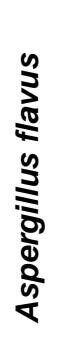 & 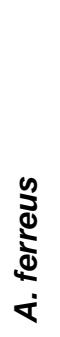 & $\begin{array}{l}n \\
5 \\
0 \\
0 \\
0 \\
0 \\
\dot{\pi}\end{array}$ & 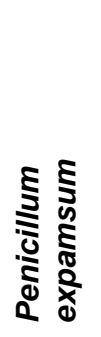 & 志 & 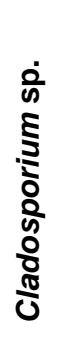 & $\begin{array}{l}\frac{0}{n} \\
\frac{\pi}{8} \\
\frac{0}{0} \\
\frac{\pi}{0}\end{array}$ & 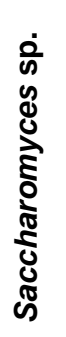 & $\begin{array}{l}\grave{\Xi} \\
\stackrel{\Xi}{\Xi} \\
\dot{x}\end{array}$ & $\begin{array}{l}\text { ò } \\
\text { ò } \\
\text { d }\end{array}$ & 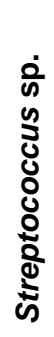 \\
\hline Itam & $\mathrm{A} 1$ & - & - & - & - & - & - & - & + & + & + & - & + & - & + & + & + & + \\
\hline Market & B1 & - & - & + & - & + & - & - & - & + & + & - & - & - & - & - & - & - \\
\hline \multirow{2}{*}{$\begin{array}{l}\text { Akpan Idem } \\
\text { Market }\end{array}$} & $\mathrm{A} 2$ & + & + & - & + & - & - & + & + & + & - & + & - & - & - & - & - & + \\
\hline & B2 & + & - & - & - & + & + & + & - & + & + & + & - & - & + & + & + & - \\
\hline \multirow{2}{*}{$\begin{array}{l}\text { Uyo main } \\
\text { Market }\end{array}$} & A3 & + & + & - & + & + & - & + & + & + & - & + & + & + & - & - & - & - \\
\hline & B3 & - & + & + & - & - & + & + & - & + & - & + & + & + & + & - & - & - \\
\hline \multirow{2}{*}{$\begin{array}{l}\text { Ikot Ekpene } \\
\text { Market }\end{array}$} & A4 & + & - & - & - & + & - & - & + & + & - & - & - & - & - & + & - & - \\
\hline & B4 & - & - & - & - & - & - & - & - & + & - & - & - & - & - & - & - & - \\
\hline
\end{tabular}

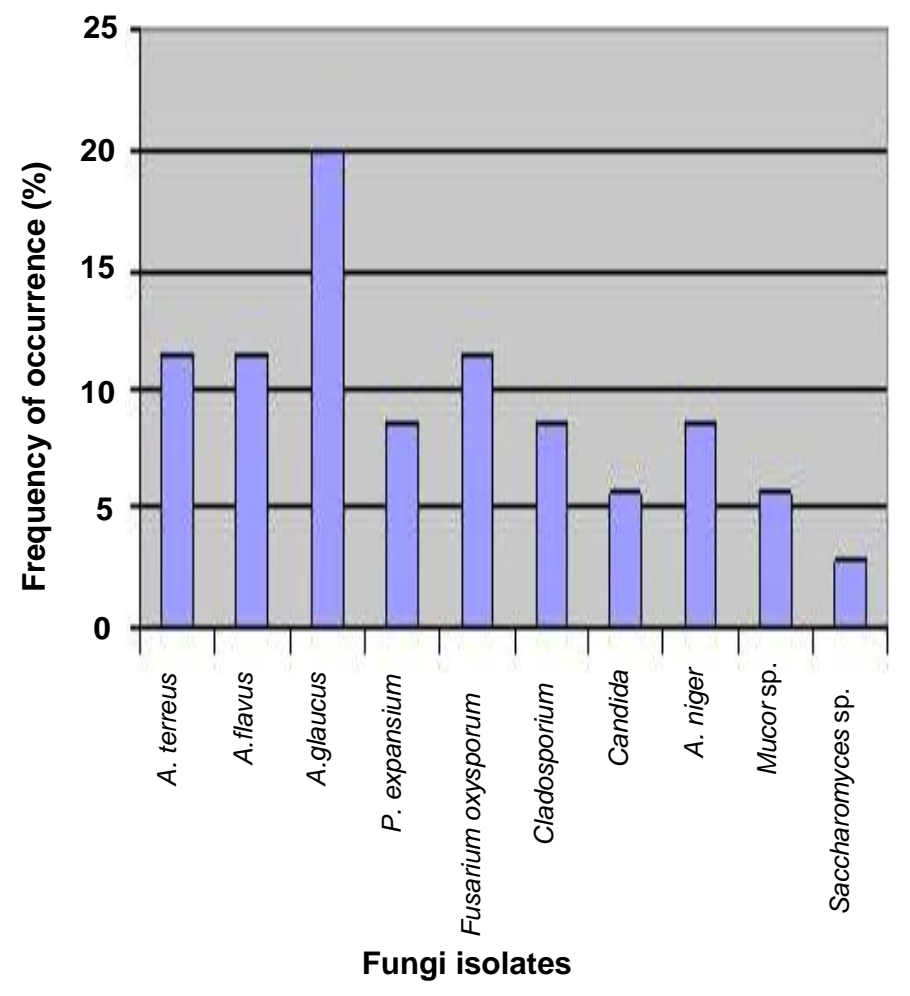

Figure 1: Frequency of occurrence (\%) of the fungi isolated from dried $H$. sabdariffa calyxes

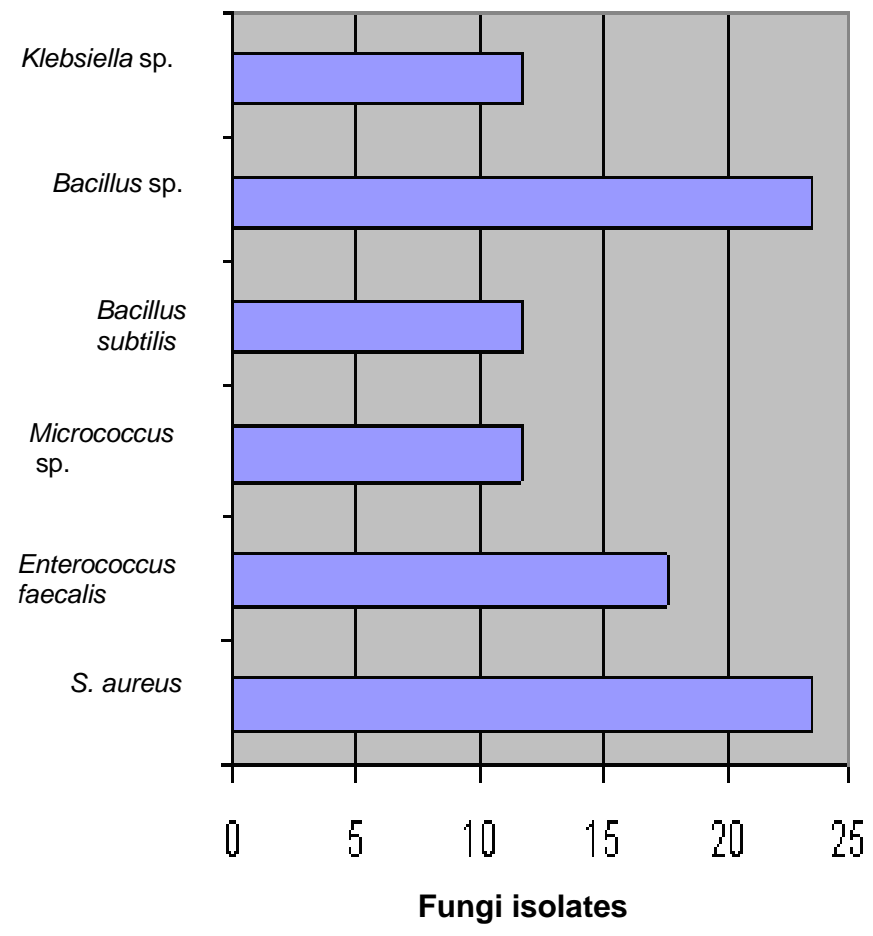

Figure 2: Frequency of occurrence (\%) of the bacteria isolated from dried $H$. sabdariffa calyxes 
Table 3: Aflatoxin $B_{1}$ Content in dried $H$. sabdariffa calyxes obtained from four different markets in Akwa Ibom State

\begin{tabular}{lllll}
\hline Sample & $\begin{array}{l}\text { Itam } \\
\text { market }\end{array}$ & $\begin{array}{l}\text { Akpan } \\
\text { Idem } \\
\text { market } \\
B_{1}\end{array}$ & $\begin{array}{l}\text { Uyo } \\
\text { main } \\
\text { market } \\
B_{1}\end{array}$ & $\begin{array}{l}\text { Ikot } \\
\text { Ekpene } \\
\text { Market } \\
B_{1}\end{array}$ \\
\hline$A_{1}$ & $B_{1}$ & 11.67 & - & - \\
$B_{1}$ & - & - & $+v e$ & 0.0 \\
$A_{2}$ & - & - & 15.76 & - \\
$B_{2}$ & - & - & - & - \\
$A_{3}$ & - & 15.76 & - & - \\
$B_{3}$ & - & 0.00 & - & - \\
$A_{4}$ & - & 0.00 & - & - \\
$B_{4}$ & - & 0.00 & - & - \\
\hline
\end{tabular}

$$
+\mathrm{ve}=\text { detected }
$$

- = not detected

The microorganism associated with dried $H$. sabdariffa calyxes are shown in Table 2 . The associated bacterial were Staphylococcus aureus, Bacillus subtilis, Bacillus sp., Enterococcus faecalis, Micrococcus sp., Klebsiella sp. The fungi and bacteria associated with the dried $H$. sabdariffa calyxes were shown in Figure 1 and 2 respectively. The fungi isolates were Aspergilles flavus, $A$. terreus, A. glaucus, $P$. expansium, Fusarium oxysporum and Cladosporum. Of the six fungi species, $A$. glaucus were the dominant species. Staphylococuss and Micrococcus species were possible contaminants from handlers. Staphylococcus aureus, a mesophile have been implicated in food poisoning outbreak of some food material. Odunfa (1988) reported that Staphylococcus aureus levels of $10^{8} \mathrm{~mL}$ were considered potential hazardous to consumers. The presence of Staphylococcus aureus is an indication of contamination by food handlers. $80 \%$ of them are being harbored by man as normal micro flora.

The fungi found associated with dried $H$. sabdariffa calyxes were mainly species of Aspergillus. This could be attributed to the prevalence of their spores in the atmosphere. The fungi species was easily trapped during the post harvest processing and handling of $H$. sabdariffa calyxes. Since most fungal spores are found in the air, the spores must have contaminated the calyx during drying. The liberated spore can easily settle on food and ceilings of room and then germinated (Okhuoya and Ayanlola, 1986).

Dongo and Ayodele (1997) have shown that Aspergillus occurred highest in the number of colonies identified from air spora of some localities. Ilondu and Iloh (2007) isolated and identified $A$. flavus and $A$. niger from sorrel drink.

In the open market, $H$. sabdariffa calyxes are displayed in large bowls and polyethylene bags for prospective consumers and in the process exposed to microbial contamination. Most of the microorganisms isolated have health implications for man except Micrococcus sp. which have not been associated with human infections. It has occasionally been isolated from human clinical specimen where it mostly represents contaminants from the skin or mucous membrane surfaces or from the environment (Koneman et al., 1992).

The occurrences of Bacillus sp. could be as a result of prevalence of their spores in environment (Jay, 1978). Bacillus species formed spore which could survive high temperatures of processing. Bacillus have been isolated from non-alcoholic beverages (Osuntogun and Aboaba, 2004, Amusa et al., 2005). Occurrences of Enterococcus faecalis during this work may be as a result of bad habit of the handlers of the dried $H$. sabdariffa calyxes, such as sneezing and coughing without covering their mouth. (Hobbs and Gilbert, 1978).

The concentration of aflatixin $B_{1}$ in the dried calyxes is shown in Table 3. It ranged from $0.00-15.76 \mu \mathrm{g} / \mathrm{kg}$. Aflatoxin $B_{1}$ was detected in samples from Uyo main market and Akpan idem market. Aflatoxin $B_{1}$, secondary fungal metabolites has been reported to be responsible for several ailments in animals including man (Fennel et al., 1973). This aflatoxin is highly carcinogenic causing hepatoxin and has been associated with acute hepatitis in men (Eaton and Groupman 1994). Prolong intake of these contaminated materials can therefore constitute to health risk and significantly reduce net population growth rate. Different species of Aspergillus and toxigenic fungi has been isolated from "zobo" juice and sorrel drink ("Zobo") (Omemu et al., 2006; llondu and Iloh, 2007). Incidence of aflatoxin in dried calyx's samples can be reduced by proper handling methods, adequate storage facilities and planting of resistant varieties.

Table 4: Proximate composition of dried $H$. sabdariffa calyxes (\%)

\begin{tabular}{llllllll}
\hline & $\begin{array}{l}\text { Moisture } \\
\text { content }\end{array}$ & \%dry matter & $\begin{array}{l}\text { Ash } \\
\text { content }\end{array}$ & $\begin{array}{l}\text { Crude } \\
\text { protein }\end{array}$ & Crude fiber & $\begin{array}{l}\text { Fat } \\
\text { content }\end{array}$ & $\begin{array}{l}\text { Total } \\
\text { carbohydrate }\end{array}$ \\
\hline $\mathrm{A}_{1}$ & 14.85 & 85.12 & 5.92 & 8.34 & 7.82 & 9.26 & 68.66 \\
$\mathrm{~B}_{1}$ & 14.61 & 85.39 & 6.03 & 8.65 & 7.69 & 9.15 & 68.53 \\
$\mathrm{~A}_{1}$ & 13.48 & 86.52 & 6.54 & 9.27 & 7.26 & 8.53 & 68.40 \\
$\mathrm{~B}_{2}$ & 14.59 & 85.41 & 6.05 & 8.57 & 7.71 & 9.18 & 68.49 \\
$\mathrm{~A}_{3}$ & 13.45 & 86.55 & 6.57 & 9.36 & 7.28 & 8.51 & 68.28 \\
$\mathrm{~B}_{3}$ & 13.17 & 86.83 & 6.74 & 9.86 & 7.43 & 8.97 & 67.00 \\
$\mathrm{~A}_{4}$ & 13.13 & 86.87 & 6.77 & 9.97 & 7.47 & 8.95 & 66.87 \\
$\mathrm{~B}_{4}$ & 13.28 & 86.72 & 6.62 & 9.64 & 7.31 & 8.63 & 68.13 \\
\hline
\end{tabular}


From the result of this study, it has been made clear those contaminants and toxigenic fungi isolated from sorrel drink was as a result of contamination of the dried calyxes of $H$. sabdariffa.

The implication of this report is that most of the dried $H$. sabdariffa calyxes presently on sale in our markets are not totally acceptable for production of "Zobo" for human consumption. Though the calyxes are properly boiled for the production of "Zobo", once the raw materials are contaminated with aflatoxin boiling does not have any effect on the potency of the toxic materials. Aflatoxin has been found to be heat stable with a melting point of between 268 to $269^{\circ} \mathrm{C}$ (Frazier and Westhoff 1998).

Nutritional analyses of the dried $H$. sabdariffa calyxes' are shown in Table 4. It was observed that the protein content, crude, fat content and carbohydrate content were very high. Roselle is often mentioned as an energy candidate yielding fiber, beverage, edible foliage and an oil seed. The extract of Roselle ("Zobo" drink) has been recommended for lowering blood pressure (Varro et al., 1981).

In conclusion, it is therefore important that both the grower and marketer of $H$. sabdariffa take necessary precautions in preventing contamination of the calyxes with fungi to reduce possible contamination and hence reduce the risk of aflatoxin and other mycotoxins that are deleterious to human health. Since the fresh calyxes is eaten raw in salads, cooked and as flavoring in cakes, wine making, beverages, syrup gelatin, puddings and dried calyxes is used for tea, jelly marmalade, ice-cream, butter, pies, sauces, soup tart (Duke and Atchley, 1984; Facciola, 1990) and zobo.

\section{REFERENCES}

Adamson, R. H., Correa, P. and Dalgard, D. W. (1973). Brief communication occurrence of primary liver carcinoma in rhesus monkey fed aflatoxin B. Journal of the National Cancer Institute 50, 549-553.

Akanya, H. O., Oyeleke, S. B., Jigam, A. A. and Lawal, F. F. (1997). Analysis of sorrel drink. Nigerian Journal of Biochemistry 12, 77-79.

ALPHA (1970). Procedure for the bacteriological examination of sea water.

Amusa, N. A., Ashaye, O. A., Aiyegbayo, A. A., Oladapo, M. O., Oni, M. O. and Afolabi, O. O. (2005). Microbiological and nutritional quality of hawked sorrel drinks (Zoborodo) (the Nigerian locally brewed soft drinks) widely consumed and notable drinks in Nigeria. Journal of Food Agriculture and Environment 3, 47-50.

AOAC (1990). Official Method of Analysis. (15 ${ }^{\text {th }} \mathrm{Ed}$.) Association of Analytical Chemists. Washington DC.

Barnet, H. L. and Hunter, B. B. (1972). Illustrated Genera of Imperfect Fungi Minneapolis Burgnees Publishing Company. Minneapolis M . N . pp. 241.

Buchana, R. E. and Gibbsons, N. E. (1974). Bergey's Manual of Determinative Bacteriology. $8^{\text {th }}$ ed. The Williams and Wilkins Co. Baltimore.
Butler, W. H. and Barnes, J. M. (1968). Carcinogenic action of groundnut meal containing aflatoxin in rats. Food Cosmetic and Toxicology 6, 135-141.

Clydescale, F. M., Main, J. H. and Francis, F. J. (1979). Roselle (Hibiscus sabdariffa) anthocyanins as colourants for beverages and gelatin deserts. Journal of Food Protection 42, 204-267.

Collins, C. H. and Lyne, P. M. (1984). Microbiological Methods. $5^{\text {th }}$ Ed. Butterworth and Co. Publisher Ltd. London 331-345.

Duke, J. A. and Atchley, A. A. (1984). Proximate analysis. In handbook of plant science in agriculture Christic, B. R. (ed) CRS press Inc., Boca Raton, Plorida.

Dongo, E. I. and Ayodele, S. M. (1997). Fungal air spora of some selected localities in Delta State University. Abraka Delta State. Bulletin of the Science Association in Nigeria 21, 9-14.

Eaton, D. L. and Groopman, J. D. (1994). The Toxicology of Aflatoxins, Academic Press, New York, NT, pp. 383-426.

FDA (1991). Sanitation of Shellfishes. Growing Areas and Seafood Safety. (F. E. Ahmed) National Academic Press Washington DC.

Facciola, S. (1990). Cornucopia - A Source Book of Edible Plants. Kampong publications ISBN 09628087-0-9. North America

Frazier, W. C. and Westhoff, D. C. (1998). Food Microbiology $4^{\text {th }}$ ed. International edition Mc Graw Hill, Singapore pp 440-441.

Fennel, D. I., Borthast, R. J., Lillenhij, E. B. and Paterson, R. E. (1973). Bright greenish yellow fluorescence and associated fungi in corn naturally contaminated with aflatoxin. Cereal chemistry 50 , 404-414.

Gopalan, C. P., Tulpule, G. and Krishnamurthy, D. (1972). Induction of hepatic carcinoma with aflatoxin in the rhesus monkey. Food and Cosmetics Toxicology 10, 519-521.

Harrigan, W. F. and McCance, M. E. (1976). Laboratory methods in food and diary microbiology. Academic Press, London. pp. 452.

Ilondu, E. M. and Iloh, A. C. (2007). Inhibition of three fungal isolates from sorrel drink ("zobo") using hurdle technique. World Journal of Agricultural Sciences 3, 339-343.

Hobbs, B. C. and Gilbert, R. J. (1978). Food poisoning and Food Hygiene $4^{\text {th }}$ ed. Edward Arnold Ltd. London 342-366.

Jay, J. M. (1978). Modern Food Microbiology $2^{\text {nd }}$ Ed. Van Nostran Reinhold. C. New York pp. 321-324.

Okhuoya, J. A. and Ayanlola, J. O. (1986). Air Spora of selected localities in Benin City. Nigeria. Nigerian Journal of Pure and Applied Science 1, 75-83.

Ojokoh, A. O., Adetuyi, F. C., Akinyosoye, F. A. and Oyetayo, V. O. (2002). Fermentation studies on Roselle (Hibiscus sabdariffa) calyces neutralized with trona. The Journal of Fd Technol in Africa, 7.3, 75-78. 
Odunfa, S. A. (1988). Microbiological quality of Yoghurt and milk drink samples in Ibadan, a Nigerian City. Journal of Agriculture 2, 43-46.

Omemu, A. M., Edema, M. O., Atayese, A. O. and Obadina, A. O (2006). A survey of the microflora of Hibiscuss sabdariffa (Roselle) and the resulting "Zobo" juice. African Journal of Biotechnology 5, 254-259.

Osuntogun, B. and Aboaba, O. O. (2004). Microbiological and physico-chemical evaluation of some non-alcoholic beverages. Pakistan Journal of Nutrition 3, 188-192.

Koneman, E. W., Allen, S. D., Janda, W. M., Schreekenberge, P. C. and Winn, Jr W. C. (1992). Colors Atlas and Textbooks of Diagnostic Microbiology. $4^{\text {th }}$ Edn T. B Lip pin cott Company, Philadelphia pp. 39-87.

Masri, M. S., Paye, J. R., and Garcia, V. C. (1969). Analysis for aflatoxin $M$ in milk. Journal of the Association of Official Analytical Chemists 51, 594600.

Seitz, I. M. and Mohr, H. W. (1977). New method for quantification of aflatoxin in corn. Cereal Chemistry 54, 179-183.

Stolof, L. and Friedman, L. (1976). Information bearing on the hazard to man from aflatoxin ingestion. PAG Bulletin 6, 21-32.

Varro, E. T., Lynn, R. and James, E. R. (1981). Planning-cognony $8^{\text {th }}$ ed. Lea Bongar, Philadelphia 520. 